\title{
Analisis Kelayakan dan Manajemen Usaha Peternakan Sapi Perah Penerima Kredit Simpan Pinjam di Koperasi SAE Pujon
}

\author{
Fahmi Arief ${ }^{1 *}$, Nenny Hariyani ${ }^{2}$, Soeharsono², Widya Paramitha Lokapirnasari ${ }^{2}$, Mirni \\ Lamid $^{2}$, Anam Al Arif ${ }^{2}$ \\ ${ }^{1}$ Progam Studi Agribisnis Veteriner, Fakultas Kedokteran Hewan, Sekolah Pascasarjana \\ Universitas Airlangga \\ ${ }^{2}$ Department Peternakan, Fakultas Kedokteran Hewan Unair \\ *Email korespondensi: budiresno12@gmail.com
}

(Diterima: 03-07-2019; disetujui 15-08-2019)

\begin{abstract}
ABSTRAK
Penelitian bertujuan untuk mengetahui analisis sistem manajemen usaha peternak sapi perah penerima kredit modal usaha di KUD SAE Pujon terhadap kelayakan usaha peternakan sapi perah dan analisis kelayakan usaha anggota peternakan sapi perah penerima kredit modal usaha di Koperasi SAE Pujon. Penelitian ini merupakan penelitian eksploratif. Penentuan lokasi dan 30 responden berdasarkan metode purposive sampling dari total semua peternak penerima kredit modal usaha yang ada di Koperasi SAE Pujon. Pengumpulan data dilakukan dengan cara teknik kuisoner, dokumentasi dan teknik wawancara. Jumlah ternak, jumlah produksi dan harga jual susu, kredit modal usaha dan manajemen peternakan adalah variabel bebas dan analisis kelayakan usaha adalah variabel tergantung. Indikator dari sistem manajemen yaitu manajemen bibit, pakan, kandang dan kesehatan. Indikator analisis kelayakan usaha yaitu break event point $(B E P)$ unit, break event point $(B E P)$ harga dan benefit cost ratio $(B / C$ Ratio). Hasil penelitian menunjukkan bahwa: (1) Hubungan SDA dan pelaksanaan kerja berpengaruh terhadap analisa usaha dalam persamaan $(\mathrm{AU}=-0,267 * \mathrm{SDA}+0,226 * \mathrm{PK})$, kemudian hubungan kredit simpan pinjam dan analisa usaha berpengaruh terhadap kelayakan usaha dalam persamaan (AKLU = $0,794 * \mathrm{BP}+0,260 * \mathrm{KSP})$.
\end{abstract}

Kata Kunci: analisis kelayakan, kredit usaha, sistem manajemen, sumber daya alam

\begin{abstract}
The cooperative also provides supporting facilities, one of which is a cooperative providing credit to the community. The study aimed to determine the analysis of the business management system of dairy farmers who received venture capital loans at KUD SAE Pujon on the feasibility of dairy farming businesses and an analysis of the business feasibility of members of the dairy farm recipients of business capital at SAE Pujon Cooperative. This research is exploratory. Location determination and 30 respondents based on the purposive sampling method of the total all farmers receiving business capital loans at the SAE Pujon Cooperative. Data collection is done by questionnaire techniques, documentation and interview techniques. The number of livestock, the amount of production and the selling price of milk, business capital credit, and livestock management are independent variables and the business feasibility analysis is a dependent variable. Indicators of the management system are the management of seeds, feed, pens, and health. Business feasibility analysis indicators are break event points (BEP) units, break event points (BEP) prices and benefit-cost ratio (B/C Ratio). The results showed that: (1) The relationship of natural resources and work implementation had an effect on business analysis in the equation ( $\mathrm{AU}=-0.267 * \mathrm{SDA}+0.226 * \mathrm{PK})$, then the relationship between savings and loans and business analysis had an effect on business feasibility in the equation (AKLU $=0.794 * \mathrm{BP}+0.260 *$ KSP).
\end{abstract}

Keywords: capital loans, feasibility analysis, management system, natural resources 


\section{PENDAHULUAN}

Peningkatan jumlah penduduk saat ini memberikan dampak yang besar terhadap peningkatan permintaan (demand) produk pangan masyarakat. Selain itu, perkembangan masyarakat saat ini lebih ke arah yang lebih maju baik dari segi pendapatan maupun tingkat pengetahuan masyarakat mengenai pentingnya nilai gizi pangan. Hal ini membuat masyarakat cenderung lebih meningkatkan konsumsi pangan yang mengandung gizi tinggi. Salah satu produk pangan yang terus mengalami peningkatan permintaan setiap tahunnya adalah susu. Susu merupakan salah satu sumber protein hewani yang sangat baik bagi kesehatan, bagi manusia, susu merupakan bahan pangan yang tersusun oleh zat-zat makanan dengan proporsi seimbang, bernilai gizi tinggi, mudah dicerna dan mengandung semua unsur makanan yang dibutuhkan (Zubaidah et al., 2002).

Peningkatan tersebut ditandai dengan meningkatnya konsumsi susu per kapita dari tahun ke tahun, mulai dari $11,09 \mathrm{~kg} / \mathrm{kapita}$ pada tahun 2013 dan meningkat hingga mencapai 12,1 kg/kapita pada tahun 2017 (Ditjen PKH, 2018). Indonesia dibandingkan dengan negara-negara ASEAN lainnya, konsumsi susu Indonesia masih relatif rendah. Konsumsi susu di singapura misalnya memiliki 48,6 kg/kapita, Malaysia 36,2 kg/kapita, Thailand 33,7 kg/kapita, Myanmar 26,7 kg/ kapita dan Filipina $17,8 \mathrm{~kg} / \mathrm{kapita}$. Selain itu, dalam hal permintaan, produksi susu dalam negeri masih belum mencukupi untuk memenuhi kebutuhan konsumsi domestik. Kondisi saat ini produksi dalam negeri hanya dapat memasok tidak lebih dari 20 persen dari permintaan nasional, sisanya 80 persen berasal dari impor (Ditjen PKH, 2018). Kondisi produksi susu segar di Indonesia saat ini sebagian besar diproduksi oleh bisnis rakyat dengan skala bisnis antara satu hingga 3,4 sapi per peternak (Ditjen PKH, 2018).

SAE Pujon adalah Koperasi Unit Desa yang berlokasi di Kecamatan Pujon. Salah satu layanan yang disediakan oleh Koperasi SAE Pujon adalah tabungan kredit yang menyediakan fasilitas kredit dan menyediakan fasilitas produksi yang diharapkan dapat meningkatkan produktivitas ternak dan bisnis. Fasilitas kredit simpan pinjam bertujuan untuk menciptakan iklim yang merangsang pertumbuhan bisnis produksi susu dalam negeri menuju swasembada susu. Sasaran fasilitas kredit koperasi simpan pinjam sapi perah adalah anggota atau calon anggota koperasi dan memiliki pengalaman peternakan sapi perah. Cara termudah untuk memajukan ternak dan meningkatkan produksi adalah dengan menambah modal, baik itu modal dari luar atau modal sendiri. Koperasi SAE Pujon menyediakan fasilitas kredit modal dengan pembayaran angsuran dari pemotongan susu yang dibayarkan setiap hari.

Berdasarkan permasalahan, perlu dilakukan analisis kelayakan pada kredit simpan pinjam untuk mengetahui sejauh mana kelayakan usaha peternakan sapi perah yang dilakukan oleh penerima kredit simpan pinjam dan secara statistik dengan analisis regresi linier sederhana untuk mengetahui pengaruh kredit simpan pinjam dan kelayakan usaha kepada peternakan sapi perah di Koperasi SAE Pujon.

\section{MATERI DAN METODE}

Penelitian ini dilakukan pada peternakan sapi perah yang menerima kredit simpan pinjam di Koperasi SAE Pujon yang berlokasi di Jalan Brigjen Abdul Manan Wijaya No. 16, Ngroto, Pujon, Malang, Jawa Timur. Penelitian dimulai pada bulan Februari hingga April 2018.

Jenis penelitian ini adalah eksploratif. Teknik pengumpulan data dilakukan dengan menggunakan kuesioner atau kuesioner dan wawancara atau observasi. Sampel diambil dengan cara non probability sampling yaitu dengan menggunakan metode purposive sampling berdasarkan 30 peternak sapi perah penerima kredit simpan pinjam yang dibagi menjadi 3 kelompok peternak yaitu kelompok peternak I dengan kepemilikan ternak 1-2 sapi perah dengan produksi susu sebanyak sebagai 515 liter / hari 10 sampel, peternak kelompok II dengan kepemilikan ternak 3-4 sapi perah dengan produksi susu 15-35 liter/hari, dan peternak kelompok III dengan kepemilikan $>4$ sapi perah dengan produksi susu $>35$ liter / hari di Koperasi SAE Pujon. 
Data yang dikumpulkan berupa data primer dan data sekunder. Pengumpulan data primer berasal dari penyediaan kuesioner, wawancara dan dokumentasi tentang (jumlah ternak, jumlah produksi, harga susu, kredit ternak, manajemen ternak, analisis keuangan dan analisis kelayakan). Data sekunder diperoleh dari institusi terkait yaitu studi literatur, literatur, majalah, serta informasi dari perusahaan terkait.

Metode analisis data penelitian ini menggunakan analisis kelayakan bisnis dan model spesifikasi dengan PLS (partial least square). Penentuan analisis kelayakan bisnis diukur dari break even point (BEP) dan benefit cost ratio ( $B / C$ Ratio). Sistem manajamen dianalisis menggunakan model program Smart PLS.

Model analisis jalur dari semua variabel laten dalam PLS terdiri dari tiga set hubungan: (1) Inner Model yang menentukan hubungan antara variabel laten (2) model luar yang menentukan hubungan antara variabel laten dengan indikator atau variabel manifes (mengukur model), dan (3) hubungan bobot di mana nilai kasus variabel laten dapat diperkirakan tanpa kehilangan generalisasi, dapat diasumsikan bahwa variabel laten dan indikator atau manifes adalah variabel pada skala nol rata-rata dan varians unit (nilai standar) sehingga parameter konstanta dihilangkan dalam model.

BEP merupakan titik dimana total pendapatan sama dengan total pengeluaran atau biaya, titik dimana laba sama dengan nol (Hansen \& Mowen (2006). Penghitungan titik BEP yang harus diketahui adalah total biaya, harga jual dan total produksi. Formula yang dapat digunakan adalah sebagai berikut:

$$
\begin{gathered}
\text { BEP Unit }=\frac{\text { Total Cost }}{\text { Sales Price }} \\
\text { BEP Price }=\frac{\text { Total Cost }}{\text { Total Product }}
\end{gathered}
$$

BEP merupakan rasio antara manfaat (manfaat) dan biaya (biaya). Perhitungan rasio biaya manfaat dapat dirumuskan sebagai berikut:

$$
\text { B/C Ratio }=\frac{\text { Total Profit }}{\text { Total Cost }}
$$

\section{HASIL DAN PEMBAHASAN}

Data peternakan yang terdiri dari pengeluaran pinjaman, jumlah produksi susu, harga jual susu dan pendapatan petani selama 15 hari, sumber daya alam (SDA), implementasi kerja dan analisis BEP bisnis mengenai efektivitas bisnis. Model data disajikan pada Gambar 1. Model data faktor analisis kelayakan diukur dari unit BEP. Indikator yang mempengaruhi analisis kelayakan bisnis adalah unit BEP dengan nilai 1. Indikator terbesar adalah unit BEP. Selain itu dapat dilihat dari nilai koefisien tercermin pengujian model data juga dapat dilakukan dengan melihat signifikansi sistem manajemen terhadap kelayakan usaha peternakan dengan melihat nilai parameter koefisien.

Tabel 1. Path coefficients

\begin{tabular}{llc}
\hline Variable Correlation & $\begin{array}{c}\text { Original } \\
\text { sampel } \\
\text { estimate }\end{array}$ \\
\hline$\circ$ & $\begin{array}{l}\text { Sumber Daya Alam (SDA) } \\
\text { terhadap Analisis Usaha }\end{array}$ & $-0,267$ \\
$\circ \quad \begin{array}{l}\text { Pelaksanaan Kerja } \\
\text { terhadap Analisis Usaha }\end{array}$ & 0,226 \\
$\circ \quad \begin{array}{l}\text { Analisis Usaha terhadap } \\
\text { Analisis Kelayakan Usaha }\end{array}$ & 0,794 \\
$\circ \quad \begin{array}{l}\text { Kredit Simpan Pinjam } \\
\text { terhadap Analisis } \\
\text { Kelayakan Usaha }\end{array}$ & 0,260 \\
\hline
\end{tabular}

Analisis kelayakan bisnis dalam penelitian ini menggunakan BEP unit, BEP harga, dan B/C Ratio. Hasil wawancara dan kuesioner diperoleh kelayakan bisnis yang dikelompokkan berdasarkan jumlah ternak dan produksi susu yaitu Grup I Grup II dan Grup III di peternakan sapi perah yang menerima kredit simpan pinjam di Koperasi SAE Pujon. 


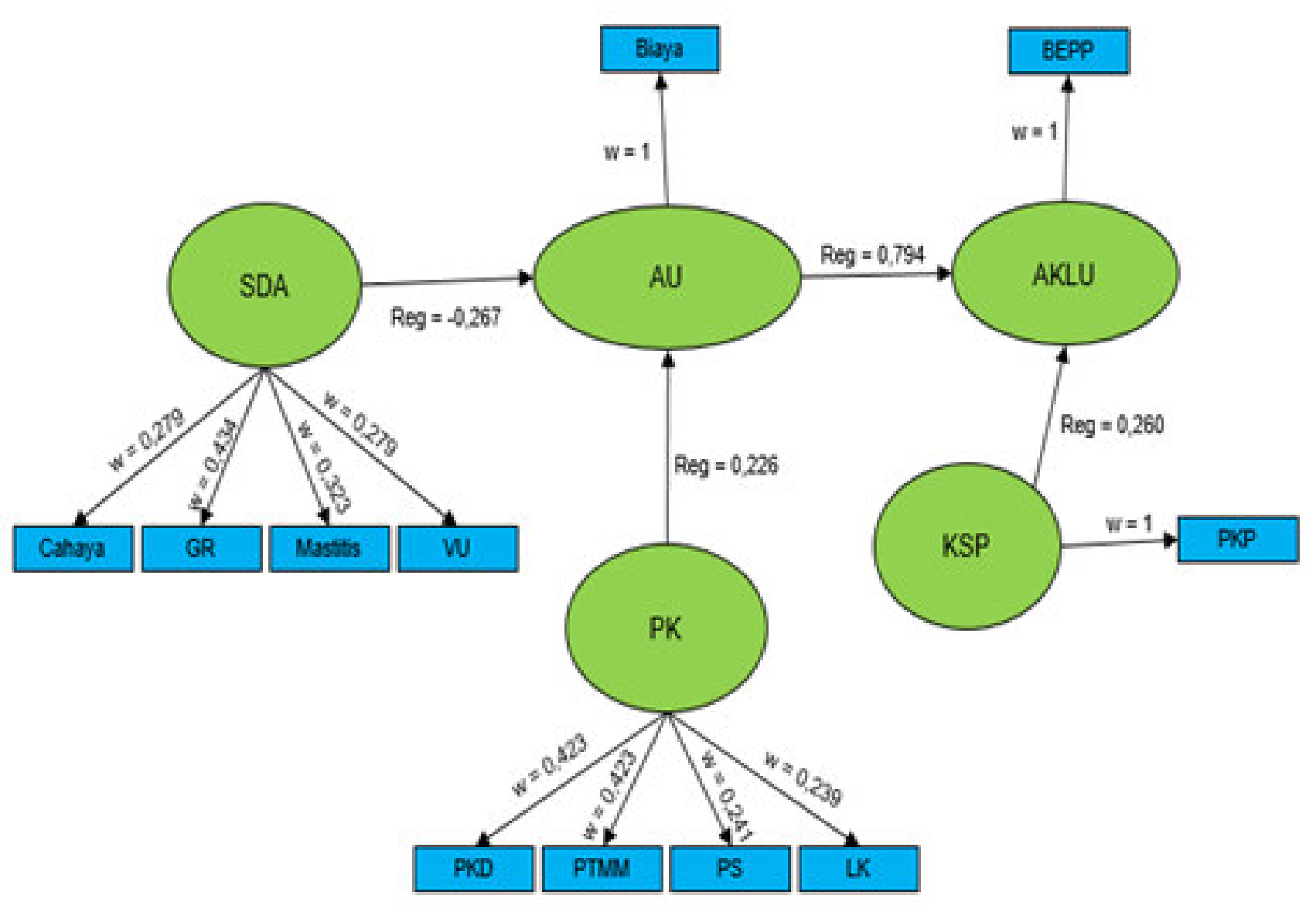

Keterangan:
a. SDA
: Sumber Daya Alam
b. PK
: Pelaksanaan Kerja
c. AKLU : Analisis Kelayakan Usaha
d. KSP : Kredit Simpan Pinjam
e. Biaya : Biaya Produksi
f. AU : Analisa Usaha
g. GR : Gangguan Reproduksi
h. VU : Ventilasi Udara
i. Mastitis : Mastitis
j. Cahaya : Intensitas Cahaya
k. PKD : Pembersihan Kandang
1. PTMM : Pembersihan Tempat Makan dan Minum
m. PS : Pembersihan Sapi
n. LK : Lantai Kandang
o. PKP : Pengeluaran Kredit Pinjaman
p. BEPP : Break Even Point (unit)

Gambar 1. Hasil Smart PLS (Bootstraping Sampel Estimated) Sumber : Output Smart PLS 
Tabel 2. Analisis kelayakan usaha

\begin{tabular}{llll}
\hline $\begin{array}{l}\text { Analisis } \\
\text { Kelayakan }\end{array}$ & Kpl I & Klp II & Klp III \\
\hline BEP (unit) & 143 liter & 237 liter & 419 liter \\
BEP (harga) & 3.189 & 3.189 & 2.848 \\
Rp/liter & Rp/liter & Rp/liter \\
\hline
\end{tabular}

Indikator SDA diukur dari cahaya, gangguan reproduksi, mastitis, dan ventilasi udara dipengaruhi secara positif oleh variabel SDA. Intensitas cahaya memiliki nilai berat $(0,279)$, gangguan reproduksi memiliki nilai berat $(0,434)$, mastitis memiliki nilai berat $(0,323)$, dan ventilasi memiliki nilai berat $(0,279)$. SDA menunjukkan pengaruh negatif pada analisis bisnis (-0.267). Indikator SDA terbesar yang memengaruhi analisis bisnis diukur dengan biaya produksi adalah gangguan reproduksi. Kondisi ini menunjukkan bahwa semakin rendah SDA akan semakin tinggi nilai analisis bisnis, maka setiap peningkatan gangguan reproduksi akan diikuti oleh kenaikan biaya produksi. Kondisi ini sesuai dengan Sudono (2003) yang berpendapat bahwa keberhasilan reproduksi adalah cermin dari keberhasilan usaha peternakan sapi perah dengan pengaturan reproduksi yang baik. Gangguan reproduksi mempengaruhi kesuburan, kesehatan, dan produksi ternak (Bahonar et al., 2009). Produksi susu yang rendah sangat terkait dengan kegagalan kehamilan karena keguguran (Weersink et al., 2002).

Indikator pelaksanaan pekerjaan yang diukur dengan pembersihan kandang, pembersihan tempat makan dan minum, pembersihan ternak dan lantai kandang memiliki efek positif pada variabel pelaksanaan pekerjaan. Pembersihan kandang dan pembersihan tempat makan dan minum memiliki nilai bobot yang sama $(0,423)$, sapi pembersih memiliki nilai bobot $(0,241)$ dan lantai kandang memiliki nilai bobot $(0,239)$. Implementasi pekerjaan menunjukkan pengaruh positif pada analisis bisnis $(0,226)$. Indikator terbesar dari pelaksanaan pekerjaan yang mempengaruhi analisis bisnis diukur dengan biaya produksi adalah pembersihan kandang dan pembersihan tempat makan dan minum. Kondisi ini menunjukkan bahwa semakin tinggi implementasi pekerjaan akan semakin tinggi analisis bisnis, maka setiap peningkatan pembersihan kandang dan pembersihan makanan dan minuman akan diikuti oleh kenaikan biaya produksi. Manajemen kandang adalah hal yang penting dalam pemeliharaan peternakan sapi perah. Kondisi ini sesuai dengan Stevenson (2001) yang menyatakan bahwa kandang harus memenuhi aspek lingkungan yang aman untuk sapi perah seperti dihindarkan dari angin kencang, terik matahari, air hujan, suhu udara malam yang dingin dan penularan penyakit. Pembersihan kandang dan pembersihan makanan dan tempat minum membutuhkan air dan disinfektan, semakin sering pembersihan kandang semakin tinggi biaya produksi yang dikeluarkan oleh air yang tinggi dan penggunaan disinfektan.

SDA dan implementasi kerja mempengaruhi analisis bisnis yang ditunjukkan dalam persamaan $(\mathrm{AU}=-0.267 * \mathrm{SDA}+0.226$ * PK). Nilai satu unit SDA lebih besar dari pada implementasi pekerjaan. Menunjukkan bahwa indikator SDA yang didominasi oleh gangguan reproduksi memiliki dampak besar pada analisis bisnis yang diukur dengan biaya produksi. Gangguan reproduksi dapat mengurangi manfaat yang diperoleh dari penanganan gangguan reproduksi sehingga meningkatkan biaya produksi pada peternakan sapi perah yang menerima tabungan dan pinjaman kredit di Koperasi SAE Pujon. Kondisi ini terkait dengan Subronto (2004) yang berpendapat bahwa produktivitas peternakan sapi perah secara langsung atau tidak langsung tergantung pada kapasitas reproduksinya. Sapi perah dengan produktivitas tinggi ditambah dengan pemilihan perkawinan yang baik akan meningkatkan produksinya.

Indikator analisis bisnis yang diukur dari biaya produksi menunjukkan pengaruh positif pada variabel analisis bisnis. Biaya produksi memiliki nilai bobot (1). Analisis bisnis menunjukkan pengaruh positif pada kelayakan bisnis $(0,794)$. Indikator terbesar analisis bisnis yang mempengaruhi analisis kelayakan bisnis diukur oleh unit BEP adalah biaya produksi. Kondisi ini menunjukkan bahwa semakin tinggi analisis bisnis akan semakin tinggi nilai kelayakan bisnis, maka setiap kenaikan biaya produksi akan diikuti oleh kenaikan Unit BEP. Biaya produksi yang lebih tinggi menyebabkan BEP unit lebih tinggi. Kondisi ini sesuai dengan Mulyadi (1993) yang berpendapat bahwa hubungan antara volume penjualan, biaya dan profitabilitas akan diperoleh pada tingkat penjualan tertentu, sehingga analisis BEP sering disebut sebagai biaya, volume, analisis laba.

Indikator kredit simpan pinjam yang diukur dengan pengeluaran kredit pinjaman 
menunjukkan pengaruh positif pada variabel kredit simpan pinjam. Pengeluaran kredit pinjaman memiliki nilai bobot (1). Kredit simpan pinjam menunjukkan pengaruh positif terhadap kelayakan usaha $(0,260)$. Indikator kredit simpan pinjam terbesar yang memengaruhi analisis kelayakan usaha yang diukur oleh unit $B E P$ adalah pengeluaran kredit pinjaman. Kondisi ini menunjukkan bahwa semakin tinggi kredit simpan pinjam akan semakin tinggi nilai kelayakan usaha, maka setiap peningkatan pengeluaran kredit pinjaman akan diikuti oleh kenaikan $B E P$ unit. Setiap peminjaman kredit simpan pinjam harus dilakukannya pelunasan terhadap pinjaman yang dipinjam. Pembayaran dilakukan setiap bulan dengan tambahan bunga sehingga pembayaran pinjaman dan tambahan bunga masuk dalam total biaya yang termasuk dalam perhitungan analisis kelayakan usaha yaitu $B E P$ unit pada peternakan sapi perah penerima kredit modal usaha yang menentukan $B E P$ unit.

Analisis usaha dan kredit simpan pinjam mempengaruhi kelayakan usaha yang ditunjukkan dalam persamaan (AKLU $=0,794 *$ $\mathrm{BP}+0,260 * \mathrm{KSP})$. Nilai satu unit analisis usaha lebih besar daripada nilai kredit simpan pinjam. Menunjukkan bahwa indikator analisis usaha yang didominasi oleh biaya produksi memiliki pengaruh besar pada kelayakan usaha yang diukur oleh BEP unit. Nilai satu unit kredit simpan pinjam lebih kecil tidak sebanding dengan biaya produksi, sehingga kredit simpan pinjam pada peternak penerima kredit simpan pinjam di Koperasi SAE Pujon tidak banyak berpengaruh pada peningkatan unit BEP. Peningkatan biaya produksi menyebabkan peningkatan unit BEP pada peternakan sapi perah yang menerima kredit simpan pinjam di Koperasi SAE Pujon. Kondisi ini sesuai dengan Munawir (2002) yang berpendapat bahwa analisis BEP bukan hanya untuk mengetahui keadaan perusahaan impas, tetapi analisis BEP dapat memberikan informasi tentang berbagai tingkat volume penjualan, serta hubungannya dengan kemungkinan penghasilan sesuai dengan tingkat penjualan yang bersangkutan.

Nilai $B E P$ unit rata-rata yang diperoleh oleh peternakan sapi perah yang menerima kredit simpan pinjam di Koperasi SAE Pujon dalam kelompok I adalah 143 liter, sedangkan pada BEP harga rata-rata yang diperoleh oleh peternakan sapi perah yang menerima kredit simpan pinjam di Koperasi SAE Pujon pada kelompok I adalah $\mathrm{Rp}$ 3.189. Nilai BEP unit rata-rata yang diperoleh peternak sapi perah yang menerima kredit simpan pinjam di Koperasi SAE Pujon di kelompok II adalah 237 liter, sedangkan pada $B E P$ harga rata-rata yang diperoleh peternak sapi perah yang menerima kredit simpan pinjam di Koperasi SAE Pujon di kelompok II adalah Rp 3.274, -. Nilai BEP unit rata-rata yang diperoleh peternak sapi perah yang menerima kredit simpan pinjam di Koperasi SAE Pujon di kelompok III adalah 419 liter, sedangkan pada BEP harga rata-rata yang diperoleh peternak sapi perah yang menerima kredit simpan pinjam di Koperasi SAE Pujon di kelompok III adalah Rp 2.848 .

Nilai $B E P$ unit tergantung pada total biaya produksi dan harga jual susu dalam satu periode (15 hari). Peternakan Kelompok III memiliki unit $B E P$ lebih tinggi dibandingkan dengan peternakan kelompok I dan kelompok II, karena rata-rata $B E P$ unit dengan produksi susu rata-rata yang dihasilkan oleh peternakan kelompok I dan kelompok II dalam satu periode lebih rendah dengan kelompok III, sedangkan kelompok Peternakan II memiliki harga BEP lebih tinggi dibandingkan dengan peternakan kelompok I dan kelompok III, karena rata-rata BEP dari harga peternak kelompok II lebih tinggi. Tingginya nilai $B E P$ harga kelompok peternak II karena ada beberapa peternak yang menjual susu dengan kualitas baik yang dipengaruhi oleh lemak dan BJ (berat jenis) susu. Kondisi ini sesuai dengan Munawir (2007) yang berpendapat bahwa biaya menentukan harga jual untuk mencapai tingkat laba yang diinginkan, harga jual mempengaruhi volume penjualan, sedangkan volume penjualan mempengaruhi volume produksi.

Nilai B/C Ratio rata-rata yang diperoleh oleh peternakan sapi perah kelompok I adalah 0,53 , rata-rata nilai $B / C$ Ratio pada peternakan sapi perah kelompok II adalah 0,53 dan untuk peternakan sapi perah kelompok III adalah 0,73. Peternakan Kelompok III memiliki B/C/ Ratio yang tinggi untuk kelompok I dan II. Semakin tinggi $B / C$ Ratio, semakin tinggi keuntungan peternakan sapi perah. Kondisi ini sesuai dengan apa yang Soepranianondo et al. (2013) menyatakan bahwa, semakin besar nilai $B / C$ Ratio berarti usaha lebih layak.

\section{KESIMPULAN}

Analisa usaha dan kredit simpan pinjam berpengaruh positif terhadap kelayakan usaha. Analisa usaha diukur oleh biaya produksi dan 
kredit simpan pinjam diukur oleh pengeluaran kredit pinjaman berpengaruh terhadap kelayakan usaha yang diukur oleh $B E P$ unit. Analisa usaha memiliki pengaruh paling besar dibandingkan kredit simpan pinjam. Pengaruh besar analisa usaha yang diukur dari biaya produksi dipengaruhi oleh SDM dan pelaksanaan kerja. SDA yang diukur oleh gangguan reproduksi dan pelaksanaan kerja yang diukur oleh pembersihan kandang dan pembersihan tempat makan dan minum. SDA memiliki pengaruh besar dibandingkan pelaksanaan kerja.

Peternakan kelompok III memiliki kelayakan usaha paling layak diantara peternak kelompok I dan kelompok II dengan nilai $B E P$ unit rata-rata pada Kelompok III adalah 419 liter. sedangkan pada nilai BEP harga rata-rata pada Kelompok III adalah Rp 2.848. Nilai B/C Ratio rata-rata pada peternak sapi perah kelompok III sebesar 0,76 .

\section{DAFTAR PUSTAKA}

Bahonar, A.R., M. Azizzadeh, M.A. Stevenson, M. Vojgani, \& M. Mahmoudi. 2009. Factors affecting days open in Holstein dairy cattle in Khorasan Razavi Province, Iran; A Cox Proportional Hazard Model. J. Ani. and Vet. Adv. 8(4):747-754.

Ditjen PKH. 2018. Statistik Peternakan. Direktorat Jenderal Peternakan dan Kesehatan Ternak, Kementerian Pertanian RI. Jakarta.

Mulyadi. 1993. Sistem Akuntansi Edisi Ketiga. Sekolah Tinggi Ilmu Ekonomi YKPN. Yogyakarta.

Mulyadi. 2007. Sistem Akuntansi. Salemba Empat. Jakarta.

Munawir, S. 2002. Analisa Laporan Keuangan. Liberty. Yogyakarta.

Munawir, S. 2007. Analisa Laporan Keuangan. Edisi Keempat. Liberty. Yogyakarta.

Soepranianondo, K., R. Sidik, D.S. Nazar, S. Hidanah, \& S.H. Warsito. 2013. Buku Ajar Kewirausahaan. Pusat Penerbitan dan Percetakan Unair. Surabaya.

Subronto, Ida T. 2004. Ilmu Penyakit Ternak II. Gadjah Mada University Press. Yogyakarta.

Sudono, A., R.F. Rosdiana, \& B.S. Setiawan. 2003. Beternak Sapi Perah Secara Intensif. Agromedia Pustaka. Jakarta.
Stevenson, J.S. 2001. Reproductive Management of Dairy Cows in High Milk-Producing Herds. Journal Dairy Science 84(3):128-143.

Weersink, A., J.A. Van Leeuwen, J. Chi, \& G.P. Keefe. 2002. Direct production losses and treatment costs due to four dairy cattle diseases. Proc. Western Canadian Dairy Seminar, Red Deer, Alberta, Canada. Adv. Dairy Technol 14:55-75.

Zubaidah, E., J. Kusnadi, \& P. Setiawan. 2002. Studi Keamanan Susu Pasteurisasi yang Beredar di Kotmadya Malang (Kajian dari Mutu Mikrobiologi dan Nilai Gizi). Jurnal Teknologi Pertanian 3(6):29-34. 